\title{
Vitamin D Receptor and Calcium-Sensing Receptor Gene Polymorphisms in Hypercalciuric Stone-Forming Patients
}

\author{
Larissa Gorayb Ferreira $^{\mathrm{a}} \quad$ Alexandre Costa Pereira $^{\mathrm{b}} \quad$ Ita Pfeferman Heilberg ${ }^{\mathrm{a}}$ \\ a Nephrology Division, Universidade Federal de São Paulo, and ' Instituto do Coração do Hospital das Clínicas, \\ Faculdade de Medicina da Universidade de São Paulo, São Paulo, Brazil
}

\section{Key Words}

Bone mineral density $\cdot$ Calcium-sensing receptor • Idiopathic hypercalciuria $\cdot$ Nephrolithiasis $\cdot$ Vitamin D receptor

\begin{abstract}
Background/Aim: Some studies have identified an association of kidney stone formation with vitamin D receptor (VDR) or calcium-sensing receptor (CaSR) polymorphisms. We aimed to evaluate the association between these polymorphisms with urinary calcium excretion $(\mathrm{uCa})$ in calciumstone-forming patients. Methods: VDR polymorphism, detected by $B s m /$ digestion, and 3 CaSR polymorphisms (G/T at codon $986, \mathrm{G} / \mathrm{A}$ at codon 990 and $\mathrm{C} / \mathrm{G}$ at codon 1011), detected by direct sequencing, were evaluated in 100 hypercalciuric (HCa) and 101 normocalciuric (NCa) calcium-stoneforming patients. Results: The total allelic frequency of VDR polymorphism was: $16 \% B B, 49 \% B b$ and $35 \% b b$. The prevalence of $b b$ genotype was significantly higher in the $\mathrm{HCa}$ when compared to the NCa group (43 vs. $27 \%$ ). With respect to CaSR polymorphisms, 986S, 990 G and 1011E variant alleles were detected, respectively, in 5, 4 and $3 \%$ of the whole sample and 5 CaSR haplotypes were identified: $94 \%$ ARQ (wildtype), 3\% SRQ, 1.5\% AGQ, 1.0\% ARE and 0.5\% AGE. No statistical differences have been observed between $\mathrm{NCa}$ and $\mathrm{HCa}$ with respect to these CaSR haplotypes. Conclusions: The present study suggested that $b b$ homozygous for VDR poly-
\end{abstract}

morphism was overrepresented in hypercalciuric stone formers. Urinary calcium excretion was not associated with CaSR polymorphism in the present sample.

Copyright $\odot 2009$ S. Karger AG, Basel

\section{Introduction}

Idiopathic hypercalciuria is one of the most common metabolic disturbances found in nephrolithiasis patients, occurring in up to $50 \%$ of cases but in less than $10 \%$ of the general population [1-3]. Idiopathic hypercalciuria represents a systemic abnormality of calcium homeostasis in which a dysregulation of calcium transport takes place in the kidneys, intestine and bones $[4,5]$. Pathophysiological mechanisms may involve a primary renal calcium leak, primary intestinal calcium hyperabsorption, or an imbalance between bone resorption and formation [6]. Such disturbances can occur simultaneously, and secondary compensatory changes involve multiple hormones such as parathyroid hormone (PTH) and 1,25dihydroxy-vitamin $\mathrm{D}_{3}\left[1,25(\mathrm{OH})_{2} \mathrm{D}_{3}\right]$ [7].

Serum $1,25(\mathrm{OH})_{2} \mathrm{D}_{3}$ levels in patients with idiopathic hypercalciuria form a continuum from normal to high [8], so that elevated circulating $1,25(\mathrm{OH})_{2} \mathrm{D}_{3}$ levels may account for the hypercalciuria in some but not all of these patients. Favus et al. [8] observed that the number of peripheral blood monocytes of vitamin D receptors (VDRs)

\section{KARGER}

Fax +4161306 1234 E-Mail karger@karger.ch www.karger.com
(C) 2009 S, Karger AG, Basel $1660-2110 / 10 / 1142-0135 \$ 26.00 / 0$

Accessible online at:

www.karger.com/nec
Ita Pfeferman Heilberg

Nephrology Division, Universidade Federal de São Paulo

Rua Botucatu, 740, Vila Clementino

São Paulo, SP 04023-900 (Brazil)

Tel. +55 115904 1697, Fax +55 115904 1684, E-Mail ipheilberg@ nefro.epm.br 
was twice as high in patients with idiopathic hypercalciuria compared to controls although the mean serum calcitriol levels were not. Therefore, a possible mechanism that could explain increased absorption of calcium in the gut, as well as bone mineral lability and abnormal renal tubule conservation of calcium would be altered tissue vitamin D response. Experimental studies have shown that the intestine, bones and kidneys of genetic hypercalciuric stone-forming rats exhibited increased numbers of vitamin $\mathrm{D}$ receptors $[5,9]$ and that prolongation of VDR half-life increases VDR tissue levels mediating increased VDR-regulated genes [9]. Finally, a link between idiopathic calcium stone formation and the microsatellite marker D12S339 (near the VDR locus) has been established in humans [10]

Almost half of the patients with idiopathic hypercalciuria have a positive family history of kidney stones [7, 11] and data from different geographic areas suggest a genetic background for hypercalciuria explaining at least $50 \%$ of its variance [11]. Nevertheless, idiopathic hypercalciuria is a complex trait that does not fit into classical Mendelian categories.

Several studies about common allelic variations in VDR in disorders of calcium metabolism, using BsmI, ApaI, TaqI and FokI restriction enzymes have been performed, but the results were controversial [12-32]. While some studies disclosed an association between VDR polymorphism and bone mineral density (BMD) [12-15], others did not [16-19]. Although the link between stone formation and VDR has not yet been clarified, and these polymorphisms do not alter the amino acid sequence of the VDR protein, allelic differences in the $3^{\prime}$ untranslated region may alter the regulation of messenger RNA stability and/or translation and thus affect vitamin D activity, or even mediate calcitriol action in the regulation of expression of other target genes involved in renal tubular calcium reabsorption [12, 27, 33]. In addition, even if a specific VDR genotype does not provide evidence for a VDR defect per se, it could be a marker for the disease that could aid in the identification of a possible disease locus [12]. Evaluation of VDR polymorphisms among kidney stone formers, hypercalciuric or not, have shown distinct findings $[16,20-32]$. Some investigators found a positive association between polymorphic variations in VDR gene with risk or recurrence of stone formation [2729] but other studies were negative [30,31]. As for urinary calcium, a few studies reported higher calcium excretion related to specific genotypes $[21,24,32]$ while others did not $[20,22,25,26]$.
The G-protein-coupled extracellular-calcium-sensing receptor (CaSR) is a key regulator of PTH secretion and renal tubular calcium reabsorption in response to blood calcium levels [34]. Activation of the renal CaSR may decrease renal tubule calcium reabsorption and cause hypercalciuria through suppression of calciumsensitive potassium channel activity. The CaSR gene is also regulated by VDR, and pathologically elevated VDR levels observed in genetic hypercalciuric stone-forming rats have been implicated in the increased renal CaSR mRNA induced by $1,25(\mathrm{OH})_{2} \mathrm{D}_{3}$, possibly contributing to hypercalciuria [35]. Three single-nucleotide polymorphisms, causing nonconservative amino acid changes have been described on exon 7, encoding the intracellular domain of CaSR. The most common single-nucleotide polymorphism is represented by a substitution of guanine/thymine at codon 986, leading to the Ala986Ser variant $[36,37]$ and the other two, less frequent substitutions, are Arg990Gly and Gln1011Glu (substitutions of adenine/guanine at codon 990 and cytosine/guanine at codon 1011, respectively) [37]. One of the pioneering studies performed by Cole et al. [36] showed a positive association between serum calcium and A986S polymorphism in women. Subsequent association studies between different CaSR polymorphisms and urinary calcium have been controversial, resulting in positive [38$42]$ or negative findings $[43,44]$. Nevertheless, only a few of these studies had been conducted in calcium-stoneforming patients $[38,42]$. Association with BMD was detected by some investigators $[45,46]$ but not by others [43, 47-49].

Therefore, the aim of the present study was to evaluate a potential association of VDR and CaSR gene polymorphisms with urinary calcium excretion in stone-forming patients.

\section{Subjects and Methods}

Two-hundred and one adult calcium-stone-forming patients (103 males and 98 females) from the Renal Lithiasis Unit of the Nephrology Division of the Federal University of São Paulo were included in the present study. Stone disease had been diagnosed on the basis of renal colic with confirmed hematuria and voiding of a calculus and/or previous surgical or endoscopic removal of stone(s), and/or radiographic evidence of stone(s). Patients were classified as normocalciuric or hypercalciuric based on the results of 24-hour urine samples available from their medical records. Data concerning the presence of other metabolic abnormalities related to stone formation were also obtained from these records. As the report of stone analysis was not available in most of the records, only those patients with evidence of uni- or bilateral ra- 
dio-opaque stones, consistent with calcium composition, were selected for this study. Exclusion criteria included: abnormal renal function, pregnant or postmenopausal women, men aged $\geq 65$ years, cystinuria, renal tubular acidosis, inflammatory bowel disease, primary hyperparathyroidism and other diseases affecting calcium metabolism (hyperthyroidism, acromegaly, sarcoidosis, diabetes or neoplasia), use of drugs such as corticosteroids, anticonvulsants, estrogen or vitamin D. Written consent was obtained from all patients and the study was approved by the Ethics Committee of the Federal University of São Paulo.

All patients had been previously submitted to a metabolic evaluation including serum determinations of calcium, creatinine, uric acid and 24-hour urine collections (mean of 2 nonconsecutive samples), under an unrestricted diet. Idiopathic hypercalciuria was defined by serum calcium within normal limits and 24-hour urinary excretion of calcium $\geq 250$ or $300 \mathrm{mg} / 24 \mathrm{~h}$ (for females and males, respectively). Hyperuricosuria was considered as urinary uric acid $>750$ or $800 \mathrm{mg} / 24 \mathrm{~h}$ (for females and males, respectively), hypocitraturia as urinary citrate $<320 \mathrm{mg} /$ $24 \mathrm{~h}$. Calcium was determined by atomic absorption spectrophotometry (Perkin Elmer Atomic Spectrophotometer 3110; Norwalk, Conn., USA), uric acid, by the uricase method (Hitachi 912; Roche, Mannheim, Germany) and citrate by an enzymatic assay using citrate lyase as described elsewhere [50]. Creatinine was determined according to a modified Jaffé reaction by isotope dilution mass spectrometry. Sodium was determined by an ion-selective electrode. BMD was assessed by dual-energy X-ray absorptiometry at lumbar spine and femoral neck sites, using a DPX model apparatus (Lunar Radiation Corporation, Madison, Wisc., USA). Data concerning evaluation of BMD were available from 146 medical records. Osteopenia was defined by a T-score value below -1.0 in the $\mathrm{L}_{2}-\mathrm{L}_{4}$ lumbar spine and/or femur neck according to WHO criteria [51].

\section{VDR and CaSR Genotyping}

Blood samples were obtained for genotyping of both VDR and CaSR polymorphisms and genomic DNA was extracted from peripheral blood leukocytes using the Puregene DNA Isolation Kit (Gentra Systems, Minneapolis, Minn., USA).

$V D R$ gene polymorphism was identified for polymerase chain reaction (PCR) amplification of the BsmI restriction site located between exon 7 and the $3^{\prime}$-UTR, using the following primers [12]: 5'-CAACCAAGACTACAAGTACCG-CGTCAGTGA-3' and 5'AACCAGCGGGAAGAGGTCAAGGG-3'. Briefly, PCR was carried out in a $50-\mu l$ reaction volume containing $500 \mathrm{ng}$ of DNA, $0.4 \mu \mathrm{M}$ of each primer, $0.5 \mathrm{nmol}$ dNTPs, $1.5 \mathrm{mM} \mathrm{MgCl}_{2}$ and $2.5 \mathrm{U}$ of Taq DNA polymerase (all reagents from Invitrogen). The PCR conditions were $94^{\circ} \mathrm{C}, 5 \mathrm{~min}, 94^{\circ} \mathrm{C}, 1 \mathrm{~min}, 61^{\circ} \mathrm{C}, 90 \mathrm{~s}, 72^{\circ} \mathrm{C}$, $2 \mathrm{~min}$, for $30 \mathrm{cycles}$ and then $72^{\circ} \mathrm{C}$ for $10 \mathrm{~min}$ and $4^{\circ} \mathrm{C}$, using an MJ Research thermal cycler. PCR products were submitted to digestion with the $B s m \mathrm{I}$ endonuclease at $65^{\circ} \mathrm{C}$ for $3 \mathrm{~h}$, and then separated electrophoretically on $2 \%$ agarose gel containing ethidium bromide. BsmI alleles were defined by capitals in the absence of the restriction site $(B)$, and lowercase letters in the presence of the restriction site $(b)$.

Part of exon 7 of the CaSR gene comprising the 3 single-nucleotide polymorphisms (G/T at codon $986, \mathrm{~A} / \mathrm{G}$ at codon 990 , and $\mathrm{C} / \mathrm{G}$ at codon 1011) were amplified by PCR as described elsewhere [38] using primers 5'-CAGAAGGTCATCTTTGGCAGCGGCA$3^{\prime}$ and 5'-TGCAGACCTGTTTCCTGGACGGTC-3', sequences
Table 1. Serum and urine biochemistry in all patients according to VDR genotypes (means $\pm \mathrm{SD}$ except for number)

\begin{tabular}{lcll}
\hline & $B B$ & $B b$ & $b b$ \\
\hline Patients & $32(16 \%)$ & $99(49 \%)$ & $70(35 \%)$ \\
Gender, M/F & $18 / 14$ & $47 / 52$ & $34 / 36$ \\
Age, years & $43 \pm 11$ & $37 \pm 10$ & $41 \pm 13$ \\
$\mathrm{sCa}, \mathrm{mg} / \mathrm{dl}$ & $9.4 \pm 0.6$ & $9.4 \pm 0.6$ & $9.4 \pm 0.4$ \\
$\mathrm{sCr}, \mathrm{mg} / \mathrm{dl}$ & $0.9 \pm 0.2$ & $0.9 \pm 0.2$ & $1.0 \pm 1.2$ \\
$\mathrm{sUrAc}, \mathrm{mg} / \mathrm{dl}$ & $5.0 \pm 1.3$ & $5.2 \pm 1.7$ & $4.9 \pm 1.8$ \\
$\mathrm{uCa}, \mathrm{mg} / 24 \mathrm{~h}$ & $263 \pm 107$ & $228 \pm 102$ & $270 \pm 102$ \\
$\mathrm{uNa}, \mathrm{mEq} / 24 \mathrm{~h}$ & $219 \pm 84$ & $227 \pm 115$ & $214 \pm 71$ \\
$\mathrm{uUrAc}, \mathrm{mg} / 24 \mathrm{~h}$ & $588 \pm 180$ & $573 \pm 275$ & $623 \pm 229$ \\
$\mathrm{uCit}, \mathrm{mg} / 24 \mathrm{~h}$ & $441 \pm 257$ & $385 \pm 254$ & $342 \pm 218$ \\
\hline
\end{tabular}

Conversion factors for SI units are: serum calcium (sCa) 0.2495 (for $\mathrm{mmol} / \mathrm{l}$ ), serum creatinine (sCr) 88.4 and serum uric acid (sUrAc) 59.48 (for $\mu \mathrm{mol} / \mathrm{l}$ ); urinary calcium (uCa) 0.02495, urinary sodium (uNa) 1.0 and urinary uric acid (uUrAc) 5.948 (for $\mathrm{mmol} /$ day); urinary citrate (uCit) 0.053 (for $\mathrm{mmol} / \mathrm{l}$ ).

that flank the polymorphic site giving an amplimer of $206 \mathrm{bp}$. Purified PCR products were submitted to direct sequencing using a ready reaction mix (ABI PRISM Big-Dye Terminator Cycle Sequencing Ready Reaction Kit; Applied Biosystems, Foster City, Calif., USA) and the same forward primer as for PCR. Sequence products were generated during 25 cycles of the following steps: $15 \mathrm{~s}$ at $96^{\circ} \mathrm{C}, 10 \mathrm{~s}$ at $50^{\circ} \mathrm{C}$, and $2 \mathrm{~min}$ at $60^{\circ} \mathrm{C}$. Nonincorporated dye terminators were removed by ethanol/sodium acetate precipitation. Afterwards, dyed samples were denatured in $20 \mu \mathrm{l}$ of Template Suppression Reagent (Applied Biosystems) at $95^{\circ} \mathrm{C}$ for $10 \mathrm{~min}$ and cooled on ice for $15 \mathrm{~min}$. The ABI PRISM 310 Genetic Analyzer (Applied Biosystems) was used for capillary electrophoresis.

\section{Statistical Analysis}

Data are presented as means \pm standard deviation (SD). The Mann-Withney test was used to compare normocalciuric versus hypercalciuric patients. The Kruskal-Wallis analysis of variance test was performed to compare differences between the different genotypes or haplotypes of each polymorphism in the normocalciuric or hypercalciuric groups of patients. The $\chi^{2}$ or Fisher's exact test was used to compare the frequencies of VDR genotypes and CaSR haplotypes in the normocalciuric and hypercalciuric groups. Relative risk to be hypercalciuric was estimated by calculation of the odds ratio (OR) and its 95\% confidence interval (95\% CI). Linkage disequilibrium between SNPs and allele and haplotype frequencies were calculated using Haploview 3.32 software. Statistical power calculations were conducted with Quanto version 1.2.3 software using empirically observed allele frequencies and the hypercalciuric phenotype. For the studied polymorphism of the VDR gene, our sample had $80 \%$ power to disclose an OR of at least 2.2 associated with the $b$ allele. For the much rarer CaSR studied polymorphisms, our sample allowed $80 \%$ power to detect OR in the order of 3.0, 3.3 and 3.7, respectively, for the 986S, 990G, and $1011 \mathrm{E}$ variant alleles. 
1

Fig. 1. VDR genotype distribution according to calcium excretion. ${ }^{*} \mathrm{p}<0.05$ versus normocalciuric. $\mathrm{NCa}=$ Normocalciuric; $\mathrm{HCa}=$ hypercalciuric.

Fig. 2. VDR genotype distribution in osteopenic $(\square)$ or normal-BMD patients (四).
2

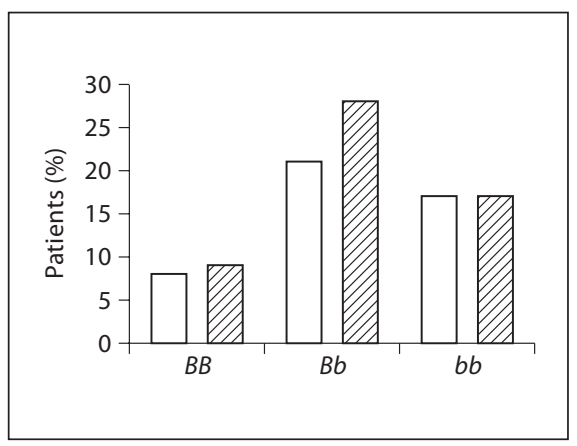

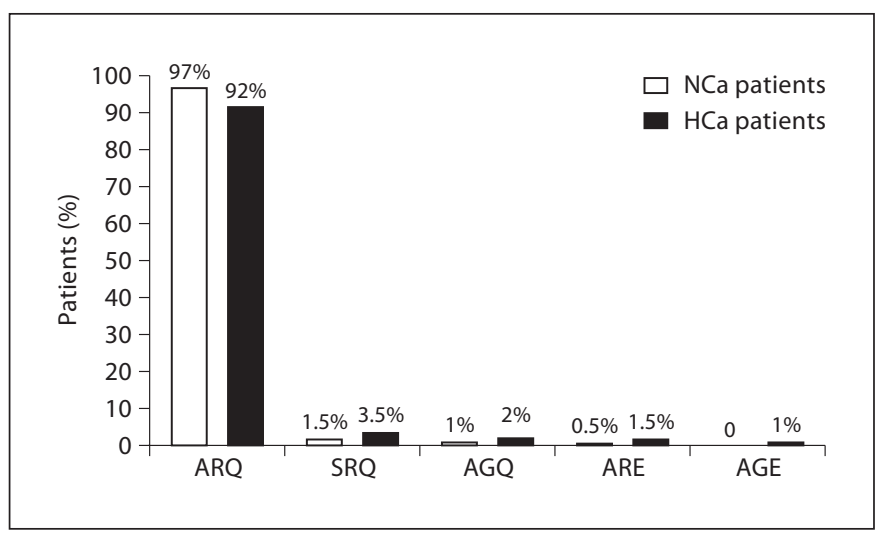

Fig. 3. CaSR haplotype distribution according to calcium excretion. $\mathrm{NCa}=$ Normocalciuric $\mathrm{HCa}=$ hypercalciuric.

\section{Results}

The allele frequencies of the VDR polymorphism in the whole sample of 201 calcium-stone-forming patients were 16,49 and $35 \%$, respectively for $B B, B b$ and $b b$, as shown in table 1 . These genotype frequencies at polymorphic sites did not deviate from those expected according to the Hardy-Weinberg equilibrium. Analysis of patients grouped by these 3 genotypes showed no differences in mean age or gender distribution. In $b b$ patients, mean urinary excretion of calcium was higher than in $\mathrm{Bb}$ patients $(270 \pm 102$ vs. $228 \pm 102 \mathrm{mg} / 24 \mathrm{~h})$, but the difference did not reach statistical significance. The other mean serum and urine biochemical parameters were not statistically different between VDR genotypes.

Patients were then classified as hypercalciuric ( $\mathrm{n}=$ $100,52 \mathrm{M} / 48 \mathrm{~F}, 38 \pm 11$ years old) or normocalciuric ( $\mathrm{n}=101,51 \mathrm{M} / 50$ F, $39 \pm 11$ years old). Hypercalciuric patients also exhibited $43 \%$ of hypocitraturia and $17 \%$ of hyperuricosuria while hypocitraturia and hyperuricos- uria were present in 34 and 3\% of normocalciuric patients, respectively. These disturbances appeared individually or in association (data not shown in tables). As shown in figure 1 , the $b b$ genotype was overrepresented in the hypercalciuric group compared to the normocalciuric group (43 vs. 27\%, p < 0.05). The distribution of VDR genotypes in osteopenic or normal BMD patients was not statistically different, as illustrated in figure 2 . Table 2 shows serum and urinary parameters in these subgroups of normo- and hypercalciuric patients grouped by VDR genotypes. Gender distribution, mean age, weight and serum parameters were not statistically different between the normo- and hypercalciuric groups with the same genotype or among genotypes, but the number of hypercalciuric patients presenting with the $b b$ genotype was significantly higher. $B b$ and $b b$ hypercalciuric patients presented significantly higher mean urinary uric acid excretion versus normocalciurics with the same genotype. Lower urinary citrate excretion was observed in $b b$ when compared with $B b$ or $B B$ hypercalciuric patients, without reaching statistical significance. When we examined the VDR alleles in normo- and hypercalciuric patients regarding recurrence, as seen in table 3 , we did not observe any statistically significant differences in genotype distribution in patients who exhibited or not new stone formation.

With respect to CaSR polymorphisms in the whole sample, the 986S, 990G, and 1011E variant alleles were detected in 5, 4 and $3 \%$ of the patients, respectively. Homozygote genotypes for these variants were not found and the allele distribution conformed to the Hardy-Weinberg equilibrium for each CaSR polymorphism. No linkage disequilibrium was observed among the 3 single nucleotide polymorphisms (data not shown). Five CaSR haplotypes were identified in the present series, named according to the amino acid coded at the 3 studied polymorphic sites. Their frequencies were: 94\% ARQ (wild type), 3\% 
Table 2. Serum and urine biochemistry in subgroups of normocalciuric and hypercalciuric patients (means \pm SD except for gender and age)

\begin{tabular}{|c|c|c|c|c|c|c|}
\hline \multirow[t]{2}{*}{ Genotype } & \multicolumn{3}{|c|}{ Normocalciuric $(\mathrm{n}=101)$} & \multicolumn{3}{|c|}{ Hypercalciuric $(\mathrm{n}=100)$} \\
\hline & $B B$ & $B b$ & $b b$ & $B B$ & $B b$ & $b b$ \\
\hline Patients & 14 & 60 & 27 & 18 & 39 & $43^{*}$ \\
\hline Gender, M/F & $9 / 5$ & $31 / 29$ & $14 / 13$ & $10 / 8$ & $20 / 19$ & $23 / 20$ \\
\hline Age, years & $41 \pm 11$ & $38 \pm 11$ & $45 \pm 12$ & $44 \pm 11$ & $36 \pm 9$ & $39 \pm 13$ \\
\hline Weight, kg & $70 \pm 10$ & $64 \pm 12$ & $71 \pm 10$ & $69 \pm 11$ & $69 \pm 12$ & $69 \pm 16$ \\
\hline $\mathrm{sCa}, \mathrm{mg} / \mathrm{dl}$ & $9.4 \pm 0.7$ & $9.5 \pm 0.8$ & $9.6 \pm 0.4$ & $9.4 \pm 0.5$ & $9.4 \pm 0.6$ & $9.3 \pm 0.5$ \\
\hline $\mathrm{sCr}, \mathrm{mg} / \mathrm{dl}$ & $0.9 \pm 0.2$ & $0.9 \pm 0.2$ & $0.9 \pm 0.2$ & $0.9 \pm 0.2$ & $0.9 \pm 0.2$ & $0.8 \pm 0.1$ \\
\hline $\mathrm{sUrAc}, \mathrm{mg} / \mathrm{dl}$ & $5.0 \pm 1.6$ & $5.0 \pm 2.0$ & $5.4 \pm 2.0$ & $4.8 \pm 1.5$ & $5.3 \pm 1.5$ & $4.6 \pm 1.6$ \\
\hline $\mathrm{uCa}, \mathrm{mg} / 24 \mathrm{~h}$ & $162 \pm 39$ & $162 \pm 38$ & $145 \pm 55$ & $346 \pm 83^{*}$ & $337 \pm 61^{*}$ & $326 \pm 60^{*}$ \\
\hline $\mathrm{uNa}, \mathrm{mEq} / 24 \mathrm{~h}$ & $211 \pm 114$ & $180 \pm 69$ & $219 \pm 68$ & $249 \pm 99$ & $226 \pm 78$ & $219 \pm 82$ \\
\hline $\mathrm{uUrAc}, \mathrm{mg} / 24 \mathrm{~h}$ & $507 \pm 177$ & $468 \pm 183$ & $485 \pm 122$ & $611 \pm 225$ & $706 \pm 316^{*}$ & $686 \pm 239^{*}$ \\
\hline $\mathrm{uCit}, \mathrm{mg} / 24 \mathrm{~h}$ & $362 \pm 197$ & $367 \pm 194$ & $356 \pm 195$ & $499 \pm 285$ & $407 \pm 318$ & $336 \pm 230$ \\
\hline
\end{tabular}

${ }^{*} \mathrm{p}<0.05$ versus normocalciuric patients with the same genotype. Conversion factors for SI units are: serum calcium sCa 0.2495 (for mmol/l), serum creatinine sCr 88.4 and serum uric acid sUrAc 59.48 (for $\mu \mathrm{mol} / \mathrm{l}$ ); urinary calcium uCa 0.02495, urinary sodium uNa 1.0 and urinary uric acid uUrAc 5.948 (for mmol/day); urinary citrate 0.053 (for $\mathrm{mmol} / \mathrm{l}$ ).

Table 3. VDR allele distribution in normo- or hypercalciuric patients with or without stone disease recurrence

\begin{tabular}{|c|c|c|c|c|c|c|}
\hline & \multicolumn{3}{|c|}{ Normocalciuric } & \multicolumn{3}{|c|}{ Hypercalciuric } \\
\hline & $B B$ & $B b$ & $b b$ & $B B$ & $B b$ & $b b$ \\
\hline Non-recurrent stones, $\mathrm{n}$ & $13(20 \%)$ & $36(54 \%)$ & $17(26 \%)$ & $11(22 \%)$ & $16(33 \%)$ & $22(45 \%)$ \\
\hline Recurrent stones, $\mathrm{n}$ & $3(10 \%)$ & $20(67 \%)$ & $7(23 \%)$ & $6(13 \%)$ & $22(50 \%)$ & $16(37 \%)$ \\
\hline New stones, $\mathrm{n}$ & $1.7 \pm 1.2$ & $2.6 \pm 1.8$ & $1.8 \pm 0.8$ & $2.3 \pm 1.6$ & $2.5 \pm 1.9$ & $2.0 \pm 1.1$ \\
\hline New stones/year, $\mathrm{n}$ & $0.4 \pm 0.3$ & $0.8 \pm 1.1$ & $1.0 \pm 1.7$ & $0.3 \pm 0.2$ & $0.6 \pm 0.7$ & $0.3 \pm 0.2$ \\
\hline
\end{tabular}

Table 4. Serum and urine biochemistry in all patients according to the CaSR haplotypes

\begin{tabular}{|c|c|c|c|c|c|}
\hline & ARQ & SRQ & AGQ & ARE & AGE \\
\hline Number & $177(94 \%)$ & $10(3 \%)$ & $8(1.5 \%)$ & $4(1.0 \%)$ & $2(0.5 \%)$ \\
\hline $\mathrm{sCa}, \mathrm{mg} / \mathrm{dl}$ & $9.4 \pm 0.6^{\mathrm{a}}$ & $9.5 \pm 0.5$ & $9.5 \pm 0.3$ & $9.6 \pm 0.6$ & $9.4 \pm 0.7$ \\
\hline $\mathrm{sCr}, \mathrm{mg} / \mathrm{dl}$ & $0.9 \pm 0.2$ & $0.7 \pm 0.2$ & $1.0 \pm 0.1$ & $0.9 \pm 0.3$ & $0.8 \pm 0.1$ \\
\hline $\mathrm{sAcUr}, \mathrm{mg} / \mathrm{dl}$ & $5.1 \pm 1.6$ & $2.9 \pm 1.4$ & $6.1 \pm 2.0$ & $5.9 \pm 1.4$ & $5.1 \pm 0.8$ \\
\hline $\mathrm{uCa}, \mathrm{mg} / 24 \mathrm{~h}$ & $239 \pm 100$ & $280 \pm 86$ & $283 \pm 112$ & $287 \pm 80$ & $300 \pm 24$ \\
\hline $\mathrm{uNa}, \mathrm{mEq} / 24 \mathrm{~h}$ & $201 \pm 67$ & $246 \pm 62$ & $214 \pm 76$ & $235 \pm 70$ & $129 \pm 79$ \\
\hline $\mathrm{uAcUr}, \mathrm{mg} / 24 \mathrm{~h}$ & $580 \pm 244$ & $582 \pm 144$ & $664 \pm 199$ & $718 \pm 369$ & $770 \pm 114$ \\
\hline $\mathrm{uCit}, \mathrm{mg} / 24 \mathrm{~h}$ & $381 \pm 232$ & $524 \pm 402$ & $289 \pm 136$ & $217 \pm 66$ & $325 \pm 329$ \\
\hline
\end{tabular}

${ }^{a}$ Mean \pm SD. Conversion factor for SI units are: serum calcium 0.2495 for $\mathrm{mmol} / \mathrm{l}$, serum creatinine 88.4 and serum uric acid 59.48 for $\mu \mathrm{mol} / \mathrm{l}$; urinary calcium 0.02495 , urinary sodium 1.0 and urinary uric acid 5.948 for $\mathrm{mmol} /$ day; urinary citrate 0.053 for $\mathrm{mmol} / \mathrm{l}$. 
SRQ, 1.5\% AGQ, 1.0\% ARE and 0.5\% AGE, as shown in table 4. Serum and urine biochemical analyses for each CaSR haplotype group were not statistically different among them. Patients with polymorphic sites (SRQ, AGQ, ARE, AGE) had an increased risk of presenting hypercalciuria when compared to the ARQ wild type (OR, 2.8; $95 \%$ CI, 1.0 to $7.5 ; \mathrm{p}=0.042$ ). However, as shown in figure 3 , the frequencies of each haplotype were not significantly different between the normo- and hypercalciuric groups.

\section{Discussion}

There is strong evidence that heredity is an important contributor to the prevalence of nephrolithiasis $[7,11,52$, 53]. The hypercalciuric phenotype has been implicated in the familial aggregation of stone formation [54]; kindreds with hypercalciuria have been well characterized $[55,56]$, and family-based studies showed a heritability for urinary calcium excretion to be more than $50 \%[57,58]$. The direct effects of $1,25(\mathrm{OH})_{2} \mathrm{D}_{3}$ on renal calcium reabsorption are complex and not well understood because of interactions with parathyroid hormone and simultaneous effects on intestine and bone. Hyperresponsiveness of genetic hypercalciuric stone-forming rats to $1,25(\mathrm{OH})_{2} \mathrm{D}_{3}$ is unique and affects the VDR-responsive gene in $1,25(\mathrm{OH})_{2} \mathrm{D}_{3}$ target tissues possibly contributing to hypercalciuria and stone formation [33]. Given the potential susceptibility locus in the vicinity of the VDR gene [10] for idiopathic stone formation and the influence of calcium-sensing receptor in calcium excretion [34], both VDR and CaSR genes have been considered as candidate genes for idiopathic hypercalciuria. In the present study, we aimed at evaluating the association of both $V D R$ and $C a S R$ polymorphisms with urinary calcium excretion in calcium-stone-forming patients.

We found a higher prevalence of the $b b$ genotype among hypercalciuric compared to normocalciuric patients. Inasmuch as $b b$ genotype has been classically related to a better BMD [12-15], its prevalence was expected to be lower among hypercalciuric patients, who traditionally exhibit higher rates of low BMD [59-61]. Anyway, our findings regarding overrepresentation of the $b b$ genotype agree well with the reports of Rendina et al. [24] and Relan et al. [32], who also observed that the presence of two copies of the $b$ allele was more common in hypercalciuric patients. Interestingly, although a higher prevalence of both (ApaI) $a a$ and (BsmI) bb genotypes in fasting hypercalciuric subjects disclosed in the former study [24], such $b b$ patients also presented a significantly lower instead of a higher mean BMD. In the present series, VDR allele distribution did not differ between osteopenic or normal BMD patients. In a previous evaluation by our group [16], conducted exclusively in hypercalciuric calcium-stone-forming patients, we also found that VDR polymorphism was not associated with loss of BMD. Nor did Vezzoli et al. [22] find an association of FokI polymorphism with BMD in hypercalciuric patients. On the other hand, although several studies in the past have suggested that multiple VDR polymorphisms (including $B s m I$ ) influence the regulation of BMD [12-15], a more recent multicenter prospective trial [17] involving around 26,000 participants, as well as other studies $[18,19]$, have not confirmed such an association. Two additional studies reported an association between $b b$ genotype with low rather than higher BMD [20,62].

Such observations of an association of VDR polymorphisms with calcium excretion but not with BMD are intriguing. According to Dawson-Hughes et al. [63] BB homozygous postmenopausal women, when exposed to low calcium intake, present less efficient intestinal calcium absorption than $b b$ women, despite similar levels of $1,25(\mathrm{OH})_{2} \mathrm{D}_{3}$, pointing to VDR as functionally different between $B B$ and $b b$ alleles. In agreement with our findings, these investigators also observed that the $b b$ group exhibited somewhat higher levels (albeit not significant) of calcium excretion than $B B$, coupled with similar BMD, irrespective of dietary calcium intake. Although the altered gut VDR status in $b b$ variants might have been responsible for a better ability to increase fractional calcium absorption [63], the patients exhibited not only slightly higher levels of urinary calcium but also somewhat lower serum PTH. The increase in calcium excretion in $b b$ genotypes may thus be ascribed to PTH suppression induced by increased activity of vitamin $\mathrm{D}$. It is noteworthy that most studies which found a positive association of $b b$ alleles with BMD, had been performed in non-calcium-stone-forming women [12-15] whereas no association was found in healthy males [19]. Since males and females were equally distributed in the present study, the samples are not comparable. We also observed that the $b b$ homozygous patients exhibited a slightly higher mean urinary calcium excretion (although not significant) than heterozygous $B b$, in accordance with other investigators who reported the same results in stone formers [21,32] or non-stone formers [64]. We believe that the small differences in mean urinary calcium excretion per genotype group might not have reached statistical significance because of the limited sample size presently analyzed. In hypercalciuric lithiasic children, Seyhan et al. [29] found 
a higher frequency of $t t$ genotypes. Conversely, other studies did not find any association between calcium excretion in nephrolithiasis patients with either BsmI polymorphism $[20,26,65]$ or other polymorphisms as TaqI, ApaI or FokI $[22,26-30,66]$. In some reports in which hypercalciuria had been ascribed to intestinal calcium hyperabsorption or renal leak, no association between $B s m I$ polymorphism with absorptive hypercalciuria was found $[20,25]$ while overrepresentation of $b b$ was observed among those exhibiting renal leak [24]. Since we found no differences of VDR alleles between absorptive or fasting hypercalciuric patients in a prior study encompassing a smaller number of patients [16], data regarding urinary calcium were pooled in the present analysis for comparison between normo- and hypercalciuric patients.

In our sample, hypercalciuric patients with one or two copies of the $b$ allele also presented a statistically higher mean urinary uric acid excretion compared to normocalciuric subgroups and a nonsignificant trend for lower urinary citrate excretion when compared to hypercalciuric $B B$ patients. In another study in stone formers, $b b$ and $T T$ genotypes were found to be associated with the presence of hypocitraturia [23]. However, the reasons why VDR polymorphisms might have affected the urinary excretion of uric acid or citrate remain unclear. Finally, we did not find any association between BsmI alleles and stone recurrence in the normocalciuric or hypercalciuric groups. None of the studies that focused on the association of VDR polymorphism with recurrence of stone disease had employed BsmI endonuclease. With regard to other polymorphisms, some authors have an association with recurrence or severity of stone disease with either the $t$ allele $[27,29]$ or the FF genotype [28], while still other investigators observed nonsignificant trends for the TT genotype [30].

Taken together, conflicting results in the literature may be due, at least in part, to small sample sizes, differences in the studied populations (pre- and postmenopausal women or kidney stone formers), sex, age, and exact VDR polymorphism that had been investigated.

With respect to CaSR polymorphisms, association with serum calcium have been reported in some studies $[12,36,67,68]$ but not in all of them $[39,47,48,69]$. Few studies focused on the association of CaSR with urinary calcium in calcium-stone-forming patients [38, 42]. In the present study, the frequencies of all $3 \mathrm{CaSR}$ polymorphisms in the whole sample were very low (up to 5\%). Although the presence of any variant allele conferred a 2.8 -fold increased risk of presenting hypercalciuria, we did not find any statistical differences among the various haplotype distributions in normocalciuric versus hypercalciuric patients. These findings are in contrast with the data of Vezzoli et al. [38] who observed that R990G polymorphism was associated with increased urinary calcium in calcium-stone-forming patients. A subsequent functional study performed by the same group [40] with transfected cells containing the 990G variant showed a gain-of-function of the CaSR. A 5.5fold increased risk for the $G$ allele to develop hypercalciuria was disclosed, but the study had not been performed in stone formers, but in osteoporotic women instead [40]. It is also possible to infer that in such a setting, hypercalciuria was consequent to increased bone resorption [70] rather than being a primary mechanism leading to loss of bone mass. On the other hand, in another functional study, Harding et al. [43] did not find any change in CaSR activity in cells transfected for the 990G allele. These investigators also reported a lack of association between R990G or other CaSR polymorphisms with urinary calcium in twin pairs [43]. In another Italian cohort, Scillitani et al. [41] reported an overrepresentation of the AGQ haplotype in stone-forming patients with primary hyperparathyroidism. Although an association with calcium clearance was disclosed in that study, the urinary calcium values had been obtained from urine spot samples rather than from 24hour urine samples, which represent the gold-standard method. One limitation of this and other studies involving the R990G polymorphism and the Q1011E is the relative rarity of the $990 \mathrm{G}$ variant. We have currently found no homozygous patients for any of the 3 polymorphisms. Nevertheless, except for recent data by Cole et al. [36], who found $2.9 \%$ of stone formers to be homozygous for 990G polymorphism, another study reported 1 single case in the control group or rates up to $1.6 \%$ of homozygous $G$ among hypercalciuric patients [40], so that the results have mostly considered the heterozygous patients for statistical purposes.

Although the present sample is not large and the statistic power of the present analysis is thus not optimal, some important points must be raised. First, genotype frequencies of either VDR or CaSR polymorphic sites did not deviate from the expected Hardy-Weinberg equilibrium in the current series. In addition, previous positive studies focusing on the association between calcium excretion and BsmI VDR polymorphisms among adult stone formers have involved around 150 patients [24, 32], an only moderately higher number than ours, while the negative studies included a much lower number of pa- 
tients, less than $40[20,21]$. As for the CaSR association studies with 24-hour calcium excretion in lithiasic patients [38], the size of the sample was similar to ours. In most of the studies aimed to address associations of polymorphisms with urinary calcium excretion, some of the difficulties on achieving a higher number of patients rely on the requirement for timed urine collection over $24 \mathrm{~h}$, which is laborious and prone to collection failure, albeit necessary for a more adequate definition of the hypercalciuric phenotype.

In conclusion, the present study showed an association between urinary calcium excretion and $b b$ genotype of VDR polymorphism, but not with CaSR polymorphisms. The described associations need to be replicated in larger samples and, ideally, should involve the use of a continuous variable (urinary calcium excretion) sampled in individuals representative of the general population.

\section{Acknowledgments}

Research supported by grants from Coordenação de Aperfeiçoamento Pessoal de Nível Superior (CAPES). The authors wish to express their thanks to Dr. Décio Brunoni for fruitful discussions and to Felipe Crispim and Tereza Kasamatsu for techni$\mathrm{cal}$ assistance. Portions of this study were presented on the occasion of the 7th World Congress of Nephrology, Rio de Janeiro, Brazil, April 21-25th, 2007.

\section{References}

1 Moe OW: Kidney stones: Pathophysiology and medical management. Lancet 2006;367: 333-344.

2 Coe FL, Evan A, Worcester E: Kidney stone disease. J Clin Invest 2005;115:2598-2608.

-3 Levy FL, Adams-Huet B, Pak CY: Ambulatory evaluation of nephrolithiasis: an update of a 1980 protocol. Am J Med 1995;98:5059.

4 Heilberg IP: Hypercalciuria; in Martini L (ed): Encyclopedia of Endocrine Diseases San Diego, Academic Press, 2004, vol 2, pp 530-536.

5 Bushinsky DA, Frick KK, Nehrke K: Genetic hypercalciuric stone-forming rats. Curr Opin Nephrol Hypertens 2006;15:403-418.

-6 Gomes SA, dos Reis LM, Noronha IL, Jorgetti V, Heilberg IP: RANKL is a mediator of bone resorption in idiopathic hypercalciuria. Clin J Am Soc Nephrol 2008;3:14461452 .

$\checkmark 7$ Moe OW, Bonny O: Genetic hypercalciuria. J Am Soc Nephrol 2005;16:729-745.

8 Favus MJ, Karnauskas AJ, Parks JH, Coe FL Peripheral blood monocyte vitamin D receptor levels are elevated in patients with idiopathic hypercalciuria. J Clin Endocrinol Metab 2004;89:4937-4943.

-9 Karnauskas AJ, van Leeuwen JP, van den Bemde GJ, Kathpalia PP, DeLuca HF, Bushinskyi DA, Favus MJ: Mechanism and function of high vitamin D receptor levels in genetic hypercalciuric stone-forming rats. J Bone Mineral Res 2005;20:447-454.

10 Scott P, Oimet D, Valiquette L, Guay G, Proulx Y, Trouvé ML, Gagnon B, Bonnardeaux A: Suggestive evidence for a susceptibility gene near the vitamin $\mathrm{D}$ receptor locus in idiopathic calcium stone formation. J Am Soc Nephrol 1999;10:1007-1013.

11 Vezzoli G, Soldati L, Gambaro G: Update on primary hypercalciuria from a genetic perspective. J Urol 2008;179:1676-1682.
12 Morrisson NA, Qi JC, Tokita A, Kelly PJ, Crofts L, Nguyen TV, Sambrook PN, Eisman JA: Prediction of bone density from vitamin D receptor alleles. Nature 1994;367:284287.

13 Fleet JC, Harris SS, Wood RJ, DawsonHughes B: The BsmI vitamin D receptor restriction fragment length polymorphism (BB) predicts low bone density in premenopausal black and white women. J Bone Miner Res 1995; 10:985-990.

14 Lazaretti-Castro M, Duarte-de-Oliveira MA, Russo EMK, Vieira JGH: Vitamin D receptor alleles and bone mineral density in a normal premenopausal Brazilian female population. Br J Med Biol Res 1997;30:929932.

15 Zambrano-Morales M, Borjas L, Fernández E, Zabala W, de Romero P, Pineda L, Morales-Machín A: Association of vitamin D receptor gene BBAAtt haplotypes with osteoporosis in post-menopausic women. Invest Clin 2008;49:29-38.

16 Heilberg IP, Teixeira SH, Martini LA, Boim MA: Vitamin D receptor gene polymorphism and bone mineral density in hypercalciuric calcium-stone-former patients. Nephron 2002;90:51-57.

- 17 Uitterlinden AG, Raslton SH, Brandi ML, Carey AH, Grinberg D, Langdahl BL, Lips P, Lorenc R, Obermayer-Pietsch B, Reeve J, Reid DM, Amedei A, Bassiti A, Bustamante M, Husted LB, Diez-Perez A, Dobnig H, Dunning AM, Enjuanes A, Fahrleitner-Pammer A, Fang Y, Karczmarewicz E, Kruk M, van Leeuwen JP, Mavilia C, van Meurs JB, Mangion J, McGuigan FE, Pols HA, Renner W, Rivadeneira F, van Schoor NM, Scollen S, Sherlock RE, Ioannidis JP: The association between common vitamin $\mathrm{D}$ receptor gene variations and osteoporosis: participant-level meta-analyses. Ann Intern Med 2006;145: 255-264.
18 McDonald HM, McGuigan FE, Stewart A, Black AJ, Fraser WD, Ralston S, Reid DM: Large-scale population-based study shows no evidence of association between common polymorphism of the VDR gene and BMD in British women. J Bone Miner Res 2006;21: 151-162.

19 Charopoulos I, Trovas G, Stathopoulou M, Kyriazopoulos P, Galanos A, Dedoussis G, Antonogiannakis E, Lyritis GP: Lack of association between vitamin $\mathrm{D}$ and calcitonin receptor gene polymorphisms and forearm bone values of young Greek males. J Musculoskelet Neuronal Interact 2008;8:196-203.

-20 Zerwekh JE, Hughes MR, Reed BY, Breslau NA, Heller HJ, Lemke M, Nasonkin I, Pak CYC: Evidence for normal vitamin D receptor messenger ribonucleic acid and genotype in absorptive hypercalciuria. J Clin Endocrinol Metab 1995;80:2960-2965.

-21 Ruggiero M, Pacini S, Amato M, Aterini S, Chiarugi V: Association between vitamin D receptor gene polymorphism and nephrolithiasis. Miner Electrolyte Metab 1999;25: 185-190.

-22 Vezzoli G, Soldati L, Proverbio MC, Adamo D, Rubinacci A, Bianchi G, Mora S: Polymorphism of vitamin D receptor gene start codon in patients with calcium kidney stones. J Nephrol 2002;15:158-164.

23 Mossetti G, Vuotto P, Rendina D, Numis FG, Viceconti R, Giordano F, Cioffi M, Scopacasa F, Nunziata V: Association between vitamin D receptor gene polymorphisms and tubular citrate handling in calcium nephrolithiasis. J Intern Med 2003;253:194-200.

24 Rendina D, Mossetti G, Viceconti R, Sorrentino M, Castaldo R, Manno G, Guadagno V, Strazzullo P, Nunziata V: Association between vitamin D receptor gene polymorphisms and fasting idiopathic hypercalciuria in recurrent stone-forming patients. Urology $2004 ; 64: 833-838$. 
-25 Soylemezoglu O, Ozkaya O, Gonen S, Misirhoglu M, Kalman S, Buyan N: Vitamin D receptor gene polymorphism in hypercalciuric children. Pediatr Nephrol 2004;19:724727.

26 Gunes S, Bilen CY, Kara N, Asci R, Bagci H, Yilmaz AF: Vitamin D receptor gene polymorphisms in patients with urolithiasis. Urol Res 2006;34:47-52.

-27 Nishijima S, Sugaya K, Naito A, Makoto M, Hatano T, Ogawa Y: Association of vitamin $\mathrm{D}$ receptor gene polymorphism with urolithiasis. J Urol 2002;167:2188-2191.

$\checkmark 28$ Liu CC, Huang CH, Wu WJ, Huang SP, Chou IH, Li CC, Chai CY, Wu MT: Association of vitamin $\mathrm{D}$ receptor (FokI) polymorphism with the clinical presentation of calcium urolithiasis. BJU Int 2007;99:1534-1538.

-29 Seyhan S, Yavascaoglu I, Kilicarslan H, Dogan HS, Kordan Y: Association of vitamin $D$ receptor gene TaqI polymorphism with recurrent urolithiasis in children. Int J Urol 2007; 14:1060-1062.

- 30 Jackman SV, Kibel AS, Ovuworie CA, Moore RG, Kavoussi LR, Jarrett TW: Familial calcium stone disease: TaqI polymorphism and the vitamin D receptor. J Endourol 1999;13: 313-316.

-31 Mittal RD, Hemant KB, Anant K, Bhandari M: Association of urokinase gene $3^{\prime}$-UTR polymorphism with calcium oxalate nephrolithiasis. J Endourol 2006;20:157-160.

-32 Relan V, Khullar M, Singh SK, Sharma SK: Association of vitamin d receptor genotypes with calcium excretion in nephrolithiatic subjects in northern India. Urol Res 2004;32: 236-240.

- 33 Yao J, Kathpalia P, Bushinsky DA, Favus MJ: Hyperresponsiveness of vitamin D receptor gene expression to 1,25 dihydroxyvitamin $\mathrm{D}_{3}$. J Clin Invest 1998;91:2223-2232.

- 34 Brown EM, MacLeod RJ: Extracellular calcium sensing and extracellular signaling. Physiol Rev 2001;81:239-297.

- 35 Yao JJ, Bai S, Karnauskas AJ, Bushinsky DA, Favus MJ: Regulation of renal calcium receptor gene expression by 1,25-dihydroxyvita$\min \mathrm{D}_{3}$ in genetic hypercalciuric stoneforming rats. J Am Soc Nephrol 2005; 16: 1300-1308.

-36 Cole DEC, Peltekova VD, Rubin LA, Hawker GA, Virth R, Hwang DM, Evrovski J, Hendy GN: A986S polymorphism of calcium-sensing receptor and circulating calcium concentrations. Lancet 1999;353:112-115.

- 37 Heath H, Oldberg S, Jackson CE, Teh BT, Hayward N, Larsson C, Buist NRM, Krapcho KJ, Hung BC, Capuano IV, Garret JE, Leppert MF: Clustered inactivating mutation and benign polymorphisms of calcium receptor gene in familial benign hypocalciuric hypercalcemia suggest receptor functional domains. J Clin Endocrinol Metab 1996;8: 1312-1317.
38 Vezzoli G, Annalisa T, Ferrucci L, Soldati L, Bianchin C, Franceschelli F, Malentacchi C, Porfirio B, Adamo D, Terranegra A, Falchetti A, Cusi D, Bianchi G, Brandi ML: Influence of calcium-sensing receptor gene on urinary calcium excretion in stone-forming patients. J Am Soc Nephrol 2002;13:25172523.

-39 Corbetta S, Eller-Vainicher C, Filopanti M, Saeli P, Vezzoli G, Arcidiacono T, Loli P, Syren ML, Soldati L, Beck-Peccoz P, Spada A: R990G polymorphism of the calcium-sensing receptor and renal calcium excretion in patients with primary hyperparathyroidism. Eur J Endocrinol 2006;155:687-692.

40 Vezzoli G, Terranegra A, Arcidiacono T, Biasion R, Coviello D, Syren ML, Paloschi V, Giannini S, Mignogna G, Rubinacci A, Ferraretto $\mathrm{A}$, Cusi D, Bianchi G, Soldati L: R990G polymorphism of calcium-sensing receptor does produce a gain-of-function and predispose to primary hypercalciuria. Kidney Int 2007;71:1155-1162.

41 Scillitani A, Guarnieri V, Battista C, De Geronimo S, Muscarella LA, Chiodini I, Cignarelli M, Minisola S, Bertoldo F, Franucci CM, Malavolta N, Piovesan A, Mascia ML, Muscarella S, Hendy GN, D’Agruma L, Cole DEC: Primary hyperparathyroidism and the presence of kidney stones are associated with different haplotypes of the calcium-sensing receptor. J Clin Endocrinol Metab 2007;92: 277-283.

42 Hamilton DC, Grover VK, Smith CA, Cole DEC: Heterogeneous disease modeling for Hardy-Weinberg disequilibrium in casecontrol studies: application to renal stones and calcium-sensing receptor polymorphisms. Ann Hum Genetics 2009;73:176183.

43 Harding B, Curley AJ, Hannan FM, Christie PT, Bowl MR, Turner JJO, Barbert M, Nasenya IG, Hampson G, Spector TD, Thakker RV: Functional characterization of calciumsensing receptor polymorphisms and absence of association with indices of calcium homeostasis and bone mineral density. Clin Endocrinol 2006;65:598-605.

44 Bollerslev J, Wilson SG, Dick IM, Devine A, Dhaliwal SS, Prince RL: Calcium-sensing receptor gene polymorphism A986S does not predict serum calcium level, bone mineral density, calcaneal ultrasound indices, or fracture rates in a large cohort of elderly women. Calcif Tissue Int 2004;74:12-17.

45 Tsukamoto K, Orimo H, Hosoi T, Miyao M, Ota N, Nakajima T, Yoshida H, Watanabe S, Suzuki T, Emi M: Association of bone mineral density with polymorphism of the human calcium-sensing receptor locus. Calcif Tissue Int 2000;66:181-183.

46 Lorentzon M, Lorentzon R, Lerner UH, Nordström P: Calcium-sensing receptor gene polymorphism, circulating calcium concentration and bone mineral density in healthy adolescent girls. Eur J Endocrinol 2001;144 257-261.
47 Takáks I, Speer G, Bajnok E, Tabák A, Nagy Z, Horváth C, Kovács K, Lakatos P: Lack of association between calcium-sensing receptor gene 'A986S' polymorphism and bone mineral density in Hungarian postmenopausal women. Bone 2002;30:849-852.

-48 Young R, Wu F, Van de Water N, Ames R, Gamble G, Reid IR: Calcium-sensing receptor gene A986S polymorphism and responsiveness to calcium supplementation in postmenopausal women. J Clin Endocrinol Metab 2003;88:697-700.

49 Pérez-Castrillon JL, Sanz A, Silva J, Justo I, Velasco E, Dueñas A: Calcium-sensing receptor gene A986S polymorphism and bone mass in hypertensive women. Arch Med Res 2006;37:607-611.

50 Heilberg IP, Boim MA, Schor N: Biochemical differences between stone formers and normal subjects; in Segura J, Conort P, Khoury S, Pak C, Preminger GM, Tolley D (eds): Stone Disease. 1st International Consultation on Stone Disease. Health Publications, Editions 21, Paris, 2003 pp 61-64.

-51 Kanis JA, Melton LJ 3rd, Christiansen C, Johnston CC, Khaltaev N: The diagnosis of osteoporosis. J Bone Miner Res 1994;9:11371141.

52 Devuyst O, Pirson Y: Genetics of hypercalciuric stone forming diseases. Kidney Int 2007;72:1065-1072.

53 Goldfarb DS, Fischer ME, Keich Y, Goldberg J: A twin study of genetic and dietary influences on nephrolithiasis: a report from the Vietnam Era Twin (VET) Registry. Kidney Int 2005;67:1053-1061.

- 54 Tessier J, Petrucci M, Trouvé ML, Valiquette L, Guay G, Ouimet D, Bonnardeaux A: A family-based study of metabolic phenotypes in calcium urolithiasis. Kidney Int 2001;60: 1141-1147.

55 Pak CY, McGuire J, Peterson R, Britton F, Harrod MJ: Familial absorptive hypercalciuria in a large kindred. J Urol 1981;126:717719.

56 Coe FL, Parks JH, Moore ES: Familial idiopathic hypercalciuria. N Engl J Med 1979; 300:337-340

57 Hunter DJ, de Lange M, Snieder H, MacGregor AJ, Swaminathan R, Thakker RV, Spector TD: Genetic contribution to renal function and electrolyte balance: a twin study. Clin Sci 2002;103:259-265.

58 Loredo-Osti JC, Roslin NM, Tessier J, Fujiwara TM, Morgan K, Bonnardeaux A: Segregation of urine calcium excretion in families ascertained for nephrolithiasis: evidence for a major gene. Kidney Int 2005;68:966-971.

59 Heilberg IP, Martini LA, Teixeira SH, Szejnfeld VL, Carvalho AB, Draibe SA, Ajzen H, Ramos OL, Schor N: Bone disease in calcium stone forming patients. Clin Nephrol 1994; 42:175-182. 
-60 Weisinger JR, Allonzo E, Bellorin-Font E, Blasini AM, Rodriguez MA, Paz-Martínez $\mathrm{V}$, Martinis R: Possible role of cytokines on the bone mineral loss in idiopathic hypercalciuria. Kidney Int 1996;49:244-250.

-61 Misael da Silva AM, dos Reis LM, Pereira RC, Futata E, Branco-Martins CT, Noronha IL, Wajchemberg BL, Jorgetti V: Bone involvement in idiopathic hypercalciuria. Clin Nephrol 2002;57:183-191.

62 Pérez A, Ulla M, Garcia V, Lavezzo M, Elias E, Binci M, Rivoira M, Centeno V, Alisio A, Talamoni NT. Genotypes and clinical aspects associated with bone mineral density in Argentine post-menopausal women. J Bone Miner Metab 2008;26:358-365.

63 Dawson-Hughes B, Harris SS, Finneran S: Calcium absorption on high and low calcium intakes in relation to vitamin D receptor genotype. J Clin Endocrinol Metab 1995;80: 3657-3661.
64 Ongphiphadhanakul B, Rajatanavin R, Chanprasertyothin S, Chailurkit L, Piaseu N, Teerarungsikul K, Sirisriro R, Komindr S, Puavilai G: Vitamin D receptor gene polymorphism is associated with urinary calcium excretion but not with bone mineral density in postmenopausal women. J Endocrinol Invest 1997;20:592-596.

65 Chen WC, Chen HY, Hsu CD, Wu JY, Tsai FJ: No association of vitamin D receptor gene $B s m I$ polymorphisms with calcium oxalate stone formation. Mol Urol 2001;5:7-10

66 Bid HK, Kumar A, Kapoor R, Mittal R: Association of vitamin D receptor-gene (FokI) polymorphism with calcium oxalate nephrolithiasis. J Endourol 2005;19:111-115.

67 Cole DE Vieth R, Trang HM, Wong BY, Hendy GN, Rubin LA: Association between total serum calcium and the A986S polymorphism of the calcium-sensing receptor gene. Mol Genet Metab 2001;72:168-174.
68 Scillitani A, Guarnieri V, De Geronimo S, Muscarella LA, Battista C, D'Agruma L, Bertoldo F, Florio C, Minisola S, Hendy GN, Cole DE: Blood ionized calcium is associated with clustered polymorphisms in the carboxyl-terminal tail of the calcium-sensing receptor gene. J Clin Endocrinol Metab 2004; 89:5634-5638.

69 Bollerslev J, Wilson SG, Dick IM, Devine A, Dhaliwal SS, Prince RL: Calcium-sensing receptor gene polymorphism A986S does not predict serum calcium level, bone mineral density, calcaneal ultrasound indices, or fracture rates in a large cohort of elderly women. Calc Tissue Int 2004;74:12-17.

70 Vezzoli G, Soldati L, Arcidiacono T, Terranegra A, Biasion R, Russo CR, Lauretani F, Bandinelli S, Bartali B, Cherubini A, Cusi D, Ferrucci L: Urinary calcium is a determinant of bone mineral density in elderly men participating in the InCHIANTI study. Kidney Int 2005;67:2006-2014. 